\title{
Classical and Non-Classical Thyroid Hormone Intracellular Pathways Involved in T Lymphoma Growth
}

\author{
Barreiro Arcos $\mathrm{ML}^{1,2}$, Sterle $\mathrm{H}^{1}$, Cayrol $\mathrm{F}^{1}$, Diaz Flaqué $\mathrm{C}^{1}$, Valli $\mathrm{E}^{1}$, Paulazo MA ${ }^{1}$, Klecha AJ ${ }^{1,3}$ \\ and Cremaschi GA ${ }^{1,3 *}$
}

\begin{abstract}
${ }^{I}$ Instituto de Investigaciones Biomédicas, Consejo Nacional de Investigaciones Científicas y Técnicas (CONICET), Facultad de Ciencias Médicas, Pontificia Universidad Católica Argentina (UCA); ${ }^{2}$ Departamento de Química Biológica, Facultad de Ciencias Exactas y Naturales, Universidad de Buenos Aires (UBA), Buenos Aires, Argentina; ${ }^{3}$ Laboratorio de Radioisótopos, Facultad de Farmacia y Bioquímica, Universidad de Buenos Aires (UBA), Buenos Aires, Argentina.
\end{abstract}

\begin{abstract}
Thyroid hormones (THs) are important regulators of cell physiology. They are essential for the normal development and growth of mammals, especially for the neural differentiation and the regulation of the metabolism and the immune system. THs also induce the proliferation of several cell types. In human and murine T cell lymphomas (TCL) this effect involves the participation of genomic and nongenomic mechanisms as it was described by the use of free THs and non-cell permeable THs coupled to agarose (TH-ag). The classic actions of thyroid hormones involve the alteration of gene transcription via specific nuclear receptors. The discovery of other effects, independent of this classic mechanism, characterizes a new and non-classic mechanism that involves different signaling pathways. Both, free THs and TH-ag, activate protein kinase $\mathrm{C}$, extracellular signal-regulated kinases and NF-kB and they increase the intracellular calcium levels. However, only the preincubation of T cells with free THs leads to an increased intracellular content of signaling enzymes. T lymphomas display high expression levels of both, the TH nuclear receptors (TRs) and the putative membrane receptor for THs, the integrin $\alpha \mathrm{V} \beta 3$, which has been demonstrated to be responsible for THs non-genomic actions. Here, we reviewed the mechanisms involved in THs modulation of the lymphocyte physiology, analyzing the interplay between genomic and nongenomic actions in T cells and its contribution in the development of lymphomas.
\end{abstract}

Keywords: Genomic signaling, integrin $\alpha \mathrm{v} \beta 3$, nongenomic signaling, thyroid hormones, $\mathrm{T}$ cell lymphoma, tumor growth.

\section{INTRODUCTION}

\section{Classical and Non-Classical Pathways of Thyroid Hormone Actions}

The thyroid hormones (THs), triiodothyronine (T3) and thyroxine (T4), modulate several physiological processes and are critical for the growth, development, differentiation and maintenance of metabolic homoeostasis [1].

THs are synthesized in the thyroid gland follicles through the iodination of tyrosine residues in thyroglobulin $[2,3]$. The pituitary gland secretes thyroid stimulating hormone (TSH) in response to the feedback from circulating THs. TSH, in turn, regulates the iodide uptake mediated by the sodium/iodide symporter in the thyroid follicles and stimulates the synthesis and secretion of THs [4].

THs are hydrophobic molecules that enter the cell by specific transporters, such as the monocarboxylate (MCT) family and organic anion transporters (OATPs). Experiments in murine models of MCT8 and Oatp1c1 deficiency demonstrate that these transporters are required to regulate the $\mathrm{THs}$ secretion [5] and the metabolism and action of THs in the mouse brain [6].

*Address correspondence to this author at the Instituto de Investigaciones Biomédicas, Facultad de Ciencias Médicas, Pontificia Universidad Católica Argentina (UCA), Alicia M. de Justo $16003^{\circ}$ piso, CABA, Buenos Aires, Argentina; Tel: +5411-4349-0200 int. 7121; Fax. 1263;

E-mail: graciela_cremaschi@uca.edu.ar
Iodothyronine deiodinases can locally increase or decrease THs signaling in a temporal and tissue specific manner, independent of the changes in TH serum concentrations. Deiodinases type 1 and 2 (D1 and D2) are active deiodinases in the conversion of $\mathrm{T} 4$ to $\mathrm{T} 3$, while the type 3 deiodinase (D3) is an inactivating deiodinase. In humans, the T4 prohormone is deiodized by the D2 activity to give the active form, T3, but in other mammals, such as rodents, the conversion of T4 into T3 is mediated mainly by the action of D1 [7]. Local activation of $\mathrm{T} 3$ at the tissue level is an important mechanism for the regulation of THs action [8]. The D3mediated inactivation of T4 to form reverse T3 (rT3), is also an important regulator of the tissue levels of T3, particularly within the thyroid axis and for the development of sensory systems [9].

The effects of THs are mediated mainly by the classical signaling pathways. This mechanism requires the THs interaction with its nuclear receptor (TR), which acts as a transcription factor. It directly interacts with specific DNA sequences on the promoter of thyroid hormone responsive element (TRE), and regulates the transcription of a wide range of target genes $[10,11,12]$. The TRs are encoded by two genes, TR $\alpha$ and TR $\beta$ [13], with distinct splice products. There are different expression patterns of these isoforms during the development or in adult tissues $[1,14]$. The $\mathbf{T R} \alpha \mathbf{1}$ is predominantly expressed in brain, heart and skeletal muscle, the TR $\beta 2$ is expressed primarily in the brain, retina and inner ear, and TR $\beta 3$ is expressed in kidney, liver, and lung 


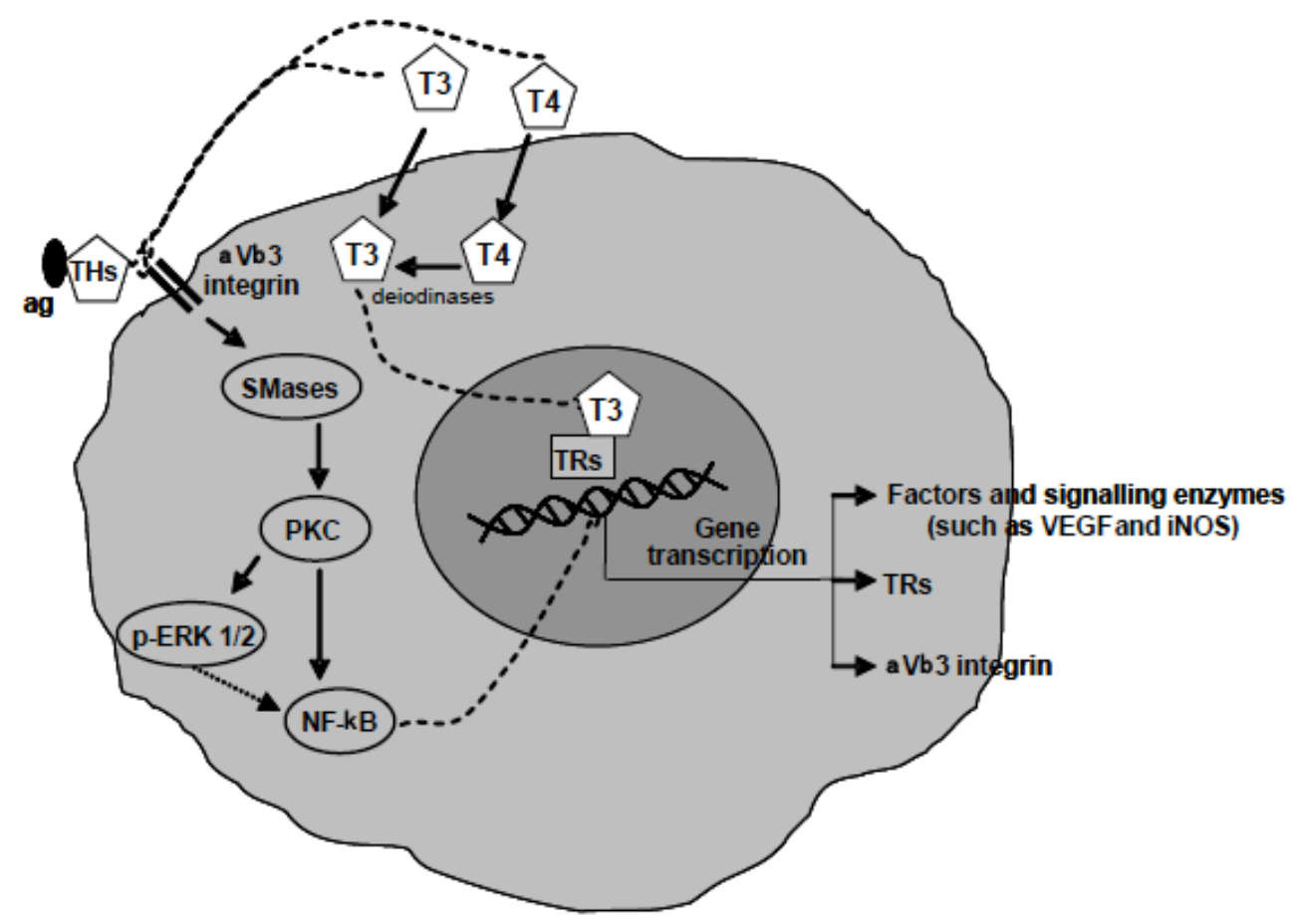

Fig. (1). Proposed Classical and non-classical thyroid hormone intracellular pathways involved in Tymphoma growth. Classical pathway of HTs actions: Free T3 or T4 hormones enter the cell cytoplasm, where T4 may be turned into T3 by deiodinases. Then, T3 enters the nucleus, interacts with the thyroid receptors and binds to the promotor secuences activating the transcription of specific genes related to the survival, growth and thyroid hormones receptors (nuclear and membrane). Non-classical pathways: free or agarose coupled THs (THsag) interacts with integrin $\alpha \mathrm{V} \beta 3$ in the plasma membrane and triggers PKC activation downstreamn esphingomielinases (SMases). Active PKC induces ERK phosphorylation and NFKB activation. Then, NFKB activates the transcription of specific genes.

[14]. TR $\alpha 2$ and $\mathbf{T R} \alpha \mathbf{3}$ isoforms are splice truncated forms and are not active. TR $\beta$ mutations have been identified in several cancers, such as hepatocellular carcinoma, renal cell carcinoma, erythroleukemias, and thyroid cancer $[15,16]$.

The interaction of the ligand-TR complex with TRE sequences induces the recruitment of coactivators and gene transcription [17]. The mechanisms involved in TH actions are complex and highly regulated by the expression of tissue-specific TH transporters and deiodinases, the expression and distribution of the TR isoforms and by the interactions with coactivators and corepressors [14, 18]. In addition, in some cases, the signals triggered by THs can be involved in a cross-talk with other signaling pathways. Thus, an important TH action is to potentiate or increment other transduction pathways [19-21]. The broad range of genes whose expression is modified by thyroid status, includes the $\mathrm{Na} / \mathrm{K}$ ATPase, the R1 adrenergic receptor, the LDL receptor, the factor for adipocyte differentiation, the mitochondrial ATPase, the HMG-CoA reductase, the bone morphogenetic protein 1 and the nerve growth factor, among others [21, 22]. THs regulate the metabolism of lipids [23], carbohydrates [24] and exert actions on cardiovascular [25], nervous [26] and immune $[27,28]$ systems.

The THs also exert actions on cell physiology through nongenomic mechanisms that do not involve the direct regulation of gene transcription by TRs [29]. Several studies have identified the integrin $\alpha \mathrm{v} \beta 3$ as specific $\mathrm{TH}$ receptor in plasma membrane, responsible for non-genomic actions of thyroid hormones [30] in several tissues, such as blood ves- sels and heart [31]. Studies on human cancer cell lines, such as breast adenocarcinoma [32], papillary and follicular thyroid carcinomas [33], glioma [34] and lung carcinoma [35], showed that the treatment with physiological concentrations of $\mathrm{T} 3$ and $\mathrm{T} 4$ leads to the activation of extracellularregulated kinases 1/2 (ERK1/2). This subsequently induces the cell proliferation as evidenced by an accumulation of PCNA. These effects were blocked by the treatment of cells with RGD, a peptide that prevents the binding of THs to the integrin $\alpha v \beta 3$.

Therefore, THs bind to $\alpha v \beta 3$ integrin in plasma membrane and initiate nongenomic actions on tumor cell proliferation mediated by ERK1/2. Phosphatidylinositol 3-kinase (PI3K) is also involved in nongenomic actions of THs, such as angiogenesis, but apparently cannot lead to tumor cell division [36]. The presence of the integrin $\alpha v \beta 3$ on vascular and tumor cells explains the proangiogenic and proliferative effects of THs on certain cancer cells, including gliomas [14].

\section{Direct Action of THs on TCL Cells Involves Both Genomic and Nongenomic Actions}

Studies using free THs and non-cell permeable THs coupled to agarose (TH-ag), have shown that both, genomic and nongenomic actions of THs, contribute to the proliferation of human and murine $\mathrm{T}$ lymphoma cell lines (TCL), thus indicating the participation of a membrane receptor for $\mathrm{THs}$ (mTR) in these cells $[37,38,39]$. The nongenomic signaling 
cascade triggered by THs through the mTR in murine TCL, involves the rapid translocation of protein kinase $\mathrm{C} \zeta(\mathrm{PKC} \zeta)$ isoform to cell membranes, mediated by the action of sphingomielinases [40]. PKC $\zeta$ activation is essential for the proliferation and survival of $\mathrm{T}$ cell lymphomas [37] and other cell types. The PKC isoenzymes seem to be important cellular regulators in hematologic malignancies. Thus, also the inhibition of PKC $\beta$ in multiple myeloma cell lines was demonstrated to suppress the signaling through the AKT pathway, thus inhibiting the proliferation and inducing apoptosis [41]. In addition, THs nongenomically induce the phosphorylation of extracellular-signal-regulated kinases (ERK1/2) and the activation of nuclear factor kappa-lightchain-enhancer of activated B cells (NF- $\mathrm{KB}$ ) on both, murine and human TCL cell lines. Both effects seem to be triggered downstream PKC activation [40]. Similarly, in HEK293A cells, it was observed that the participation of PKC $\delta$ is essential for ERK2-mediated activation of NF- $\mathrm{KB}$ and iNOS, promoting cell survival [42]. Furthermore, both free THs and $\mathrm{TH}-\mathrm{ag}$ increased the protein and mRNA levels of the TH nuclear receptor TR $\alpha 1$ in murine TCLs, but the inducible nitric oxide synthase (iNOS) protein and mRNA levels as well as its enzymatic activity were only increased by free hormones [40].

We have recently demonstrated that integrin $\alpha v \beta 3$ is the mTR in human TCL cell lines. Proliferative actions of THs were demonstrated in a panel of 9 cell lines of TCL representing the different subtypes of the human pathology. These effects were abrogated by the RGD peptide and were not observed when knocking down the integrin $\alpha v \beta 3$ with siRNA against both $\alpha v \beta 3$ integrins [39].

These contributions indicate that THs are capable of sustained TCL proliferation by both classical and non-classical signaling pathways.

The control of the cell cycle is the most important mechanism for the regulation of cell division. In several cell types, including TCL, THs can modulate the cell cycle, through the regulation of the levels of expression of cyclins, cyclin-dependent kinases and cell cycle inhibitors [43]. In rat GC pituitary cells, T3 induces the acceleration of the G1 phase of the cell cycle leading to an increase of cell proliferation [44]. In addition, the treatment of rat cardiomyocytes with T3 increases the expression levels of cyclin D1 and thus induces the cell cycle progression [45]. In accordance with these results, the increment of Cyclin D1 has been widely linked to the TH-mediated regulation of the cell cycle in various cell types [46-47].

The cell division rate of TCLs is also increased by THs. This effect is mediated by the induction of the cyclins expression and the reduction of the expression levels of cyclindependent kinases and tumor suppressor genes. In vitro studies have shown that the action of THs on cell division can lead to an exacerbation of cell cycle progression that could, eventually, induce cellular apoptosis as a result of the loss of checkpoint mechanisms and the inactivation of signaling pathways [40]. However, although solid tumor TCLs growing in hyperthyroid mice showed an increased number of apoptotic cells, this is not related to remission [43]. This suggests that the in vivo effects of THs on the tumor growth are probably modulated by other factors present in the tumor microenvironment.

Another important process for tumor growth and development is the production of angiogenic factors. These factors allow the vascularization of tumor tissue. In this regard, it was shown that THs, acting via the integrin $\alpha v \beta 3$, induce multiple vascular growth factor receptors as well as their ligands, such as vascular endothelial growth factor (VEGF), basic fibroblast growth factor (bFGF), platelet-derived growth factor (PDGF) and epidermal growth factor (EGF), as well as angiogenic chemokines [48]. THs may also increase the activity of bradykinin and angiotensin II, thus contributing to the vascularization [48].

In human breast cancer cells, the inhibition of integrin $\alpha v \beta 3$ by tetraiodothyroacetic acid (TETRAC) blocked the nongenomic proliferative and proangiogenic actions of $\mathrm{THs}$ through the inhibition of the angiogenic effects of VEGF and bFGF. These cells also showed an increase in the proapoptotic genes expression, demonstrating that the THs are essential for cell survival $[49,50]$. On human TCLs, TH-ag induce the expression of $V E G F$ genes and the VEGF production, effects that were impaired when knocking-down the integrin $\alpha \mathrm{V} \beta 3$ expression with the corresponding siRNA, thus confirming that these mechanisms are also present in malignant $T$ cells [39]. In addition, the integrin $\alpha v \beta 3$ engages in crosstalk with the VEGF and bFGF receptors, so THs may favor this interaction [51].

\section{Thyroid Status Modulates in vivo Growth of TCL}

The direct actions of THs are generally studied in isolated cells with the addition of exogenous hormones. This does not precisely reproduce what happens in the intact organism. As THs stimulate the proliferation of various cell lines and induce the production of angiogenic factors, this could contribute to the tumor growth in vivo in hyperthyroid subjects.

Hyperthyroidism has been described as a risk factor for the development of ovarian [52], pancreas [53], lung and prostate [54] cancers. On the other hand, clinical hypothyroidism is associated with greater survival in various types of malignant processes, but the mechanisms involved are unknown [55]. Cristofanilli et al. [56] have described a reduced incidence of mammary carcinoma in hypothyroid patients, and Hercbergs [57] has suggested that hypothyroidism could contribute to spontaneous or therapy-induced tumor regression. However, other authors describe hypothyroidism as a risk factor for the development of liver and breast cancer [58, 59].

Controversial effects of thyroid status in tumor development could be related to the known regulation that THs exert on the immune response [60]. In vivo studies have shown the modulatory action of thyroid status on the growth of TCL. T lymphoma cells, growing as solid tumors in hyperthyroid mice, exhibited a higher growth rate and a greater volume than euthyroid or hypothyroid animals. This was accompanied by increased levels of PCNA. In addition, tumor sections from these tumors showed high vascularization, low levels of necrosis and increased proliferative indexes despite displaying high apoptosis [43]. Deregulation of the balance 
between apoptosis and proliferation is a frequent feature in several human lymphoproliferative syndromes that is related to tumor aggressiveness [61]. Consistent with these findings, Martínez Iglesias et al. [62] observed a smaller tumor development in hypothyroid mice inoculated with xenografts of human hepatocarcinoma and breast cancer lines. In addition, the volume and vascular support of xenografts of human pancreatic, kidney, lung, and breast cancers are downregulated by inhibition of the integrin $\alpha v \beta 3$ by TETRAC [50].

Differential expression of cell cycle regulatory proteins was also observed in murine models of TCL with different thyroid status. The levels of cyclins D1 and D3 were augmented in TCL tumors of hyperthyroid animals, whereas the cell cycle inhibitors p16/INK4A and p27/Kip1 and the tumor suppressor p53 were increased in these mice [43]. Cyclin D1 and D3 has been widely linked to the T-cell lymphomagenesis and several authors have associated its positive regulation with a poor prognosis in patients with lymphoblastic lymphoma [63-67]. Negative regulation of the tumor suppressor genes expression, such as PTEN [68], Rb [64, 65, 69] and p53 [64, 70, 71] has been described as important factors for the development of lymphoid malignancies. TCL tumors growing in hyperthyroid mice also showed increased genomic expression levels of cyclin E [43]. Increased levels of this cyclin, together with a reduction in $\mathrm{p} 27 / \mathrm{Kip} 1$ levels, has also been described in $\mathrm{T}$ cell lymphomas [72-74]. These findings are consistent with previous studies on liver regeneration in hyperthyroid rats, that showed increased expression levels of cyclins D1, E and A, and decreased levels of p16/INK4A and p27/Kip1 [75].

Several studies have shown that THs induce angiogenesis in normal and tumor tissues. Induction of angiogenesis mediated by THs has been shown in brain through the action of VEGF-1 and FGF-2 [76]. TCL growing in hyperthyroid mice, but not in hypothyroid mice, showed increased intratumoral and peritumoral vasculogenesis [43].

Also in hepatocytes, hepatoma cells and kidney and lung carcinomas an increased production of VEGF was observed, induced by the interaction of $\mathrm{T} 3$ with its nuclear receptor [77]. However, evidence suggests that the proangiogenic effect of THs is mediated by integrin $\alpha v \beta 3$. In this sense Bergh [30] has described T4-induced angiogenesis in a chicken chorioallantoic membrane angiogenesis model that was reversed by the pharmacologic or genomic inhibition of integrin $\alpha v \beta 3$. Davis et al. [78] also described in this model that T4-ag and T4 showed similar angiogenic effects. The interaction of THs with the integrin $\alpha v \beta 3$ induces the phosphorylation of ERK, activating several transcription factors that lead to an increase of angiogenic factors, such as FGF-2, VEGF, and Ang-2 [79]. In human TCL xenografts in immunodeficient mice it was also demonstrated that the knockdown of integrin $\alpha \mathrm{V} \beta 3$, decreases tumor volume and vascularization (Cayrol et al, 2014), strengthening the contribution of THs to angiogenesis also in TCL.

\section{CONCLUDING REMARKS}

THs are involved in the modulation of TCL proliferation in vitro and in vivo, through the induction of signaling pathways that involved both the TRs and the mTR in the integrin $\alpha \mathrm{V} \beta 3$. Among the signals triggered via the integrin, the acti- vation of sphingomyelinases, $\mathrm{PKC}, \mathrm{NF}-\kappa \mathrm{B}$ and ERK play a crucial role in TCL growth. These mechanisms also involve TH-mediated modulation of cell cycle regulators and angiogenic factors. These results indicate that the integrin $\alpha \mathrm{V} \beta 3$ exerts a novel modulation of TCL pathophysiology and that its inhibition would be an effective treatment for TCL patients.

\section{CONFLICT OF INTEREST}

The authors confirm that this article content has no conflict of interest.

\section{ACKNOWLEDGEMENTS}

Financial contributions to the work being reported are grants from the National Agency for scientific and technical promotion (PICT 2012-1328) and from the University of Buenos Aires (UBACYT 2011-2014 No 20020100100291 and UBACYT 2014-2017 No 20020130100289BA).

\section{REFERENCES}

[1] Oetting, A.; Yen, P.M. New insights into thyroid hormone action Best Pract. Res. Clin. Endocrinol. Metab.; 2007, 21(2), 193-208.

[2] Zimmermann, M.B. Iodine deficiency. Endocr. Rev., 2009, 30(4), 376-408.

[3] Rubio, I.G.; Medeiros-Neto, G. Mutations of the thyroglobulin gene and its relevance to thyroid disorders. Curr. Opin. Endocrinol. Diabetes Obes., 2009, 16(5), 373-378.

[4] Chiamolera, M.I.; Wondisford, F.E. Minireview: Thyrotropinreleasing hormone and the thyroid hormone feedback mechanism. Endocrinology, 2009, 150(3), 1091-1096.

[5] Di Cosmo, C.; Liao, X.H.; Dumitrescu, A.M.; Philp, N.J.; Weiss, R.E.; Refetoff, S. Mice deficient in MCT8 reveal a mechanism regulating thyroid hormone secretion. J. Clin. Invest., 2010, 120(9), 3377-3388.

[6] Mayerl, S.; Visser, T.J.; Darras, V.M.; Horn, S.; Heuer, H. Impact of Oatp1c1 deficiency on thyroid hormone metabolism and action in the mouse brain. Endocrinology, 2012, 153(3),1528-1537.

[7] Gereben, B.; Zavacki, A.M.; Ribich, S.; Kim, B.W.; Huang, S.A.; Simonides, W.S.; Zeöld, A.; Bianco, A.C. Cellular and molecular basis of deiodinase-regulated thyroid hormone signaling. Endocr. Rev., 2008, 29(7), 898-938.

[8] Schweizer, U.; Weitzel, J.M.; Schomburg, L. Think globally: act locally. New insights into the local regulation of thyroid hormone availability challenge long accepted dogmas. Mol. Cell Endocrinol., 2008, 289(1-2), 1-9.

[9] Hernandez, A.; Martinez, M.E.; Liao, X.H.; Van Sande, J.; Refetoff, S.; Galton, V.A.; St Germain, D.L. Type 3 deiodinase deficiency results in functional abnormalities at multiple levels of the thyroid axis. Endocrinology, 2007, 148(12), 5680-5687.

[10] Bassett, J.H.; Harvey, C.B.; Williams, G.R. Mechanisms of thyroid hormone receptor-specific nuclear and extra nuclear actions. Molecular and Cellular Endocrinology, 2003, 213, 1-11.

[11] Lazar, M,A. Thyroid hormone action: a binding contract. J. Clin. Invest., 2003, 112, 497-499.

[12] Moeller, L.C.; Broecker-Preuss, M. Transcriptional regulation by nonclassical action of thyroid hormone. Thyroid Research, 2011, 4(Suppl 1) S6.

[13] Harvey, C.B.; Williams, G.R. Mechanism of thyroid hormone action. Thyroid, 2002, 12, 441-446.

[14] Cheng, S.Y.; Leonard, J.L.; Davis, P.J. Molecular aspects of thyroid hormone actions. Endocr. Rev., 2010, 31(2), 139-170.

[15] Rosen, M.D.; Chan, I.H.; Privalsky, M.L. Mutant thyroid hormone receptors (TRs) isolated from distinct cancer types display distinct target gene specificities: a unique regulatory repertoire associated with two renal clear cell carcinomas. Mol. Endocrinol., 2011, 25(8), 1311-1325.

[16] Chan, I.H.; Privalsky, M,L. A conserved lysine in the thyroid hormone receptor-alpha1 DNA-binding domain, mutated in hepatocel- 
lular carcinoma, serves as a sensor for transcriptional regulation. Mol. Cancer Res., 2010, 8(1), 15-23.

[17] Liu, Y.; Xia, X.; Fondell, J.D.; Yen, P.M. Thyroid hormoneregulated target genes have distinct patterns of coactivator recruitment and histone acetylation. Mol. Endocrinol., 2006, 20(3), 483490 .

[18] Williams, G.R. Neurodevelopmental and neurophysiological actions of thyroid hormone. J. Neuroendocrinol., 2008, 20(6), 784794.

[19] Bernal, J. Thyroid hormone receptors in brain development and function. Nat. Clin. Pract. Endocrinol. Metab., 2007, 3(3), 249259.

[20] Liu, Y.Y.; Brent, G.A. Thyroid hormone crosstalk with nuclear receptor signaling in metabolic regulation. Trends Endocrinol. Metab., 2010, 21(3), 166-173.

[21] Figueiredo, N.B.; Cestari, S.H.; Conde, S.J.; Luvizotto, R.A.; De Sibio, M.T.; Perone, D.; Katayama, M.L.; Carraro, D.M.; Brentani, H.P.; Brentani, M.M.; Nogueira, C.R. Estrogen-responsive genes overlap with triiodothyronine-responsive genes in a breast carcinoma cell line. Scientific World Journal, 2014, 969404. doi: 10.1155/2014/969404. eCollection 2014

[22] Varga, F.; Rumpler, M.; Zoehrer, R.; Turecek, C.; Spitzer, S.; Thaler, R.; Paschalis, E.P.; Klaushofer, K. T3 affects expression of collagen $\mathrm{I}$ and collagen cross-linking in bone cell cultures. Biochem. Biophys. Res. Commun., 2010, 402(2), 18018-5.

[23] Cordeiro, A.; Souza, L.L.; Einicker-Lamas, M.; Pazos-Moura, C.C. Non-classic thyroid hormone signalling involved in hepatic lipid metabolism. J. Endocrinol., 2013, 216(3), R47-57.

[24] Potenza, M.; Via, M.A.; Yanagisawa, R.T. Excess thyroid hormone and carbohydrate metabolism. Endocr Pract., 2009, 15(3), 254262.

[25] Martínez-Sánchez, N.; Alvarez, C.V.; Fernø, J.; Nogueiras, R.; Diéguez, C.; López, M. Hypothalamic effects of thyroid hormones on metabolism. Best Pract. Res. Clin. Endocrinol. Metab., 2014, 28(5), 703-712.

[26] Remaud, S.; Gothié, J.D.; Morvan-Dubois, G.; Demeneix, B.A. Thyroid hormone signaling and adult neurogenesis in mammals. Front Endocrinol (Lausanne), 2014, 5, 62.

[27] Klecha, A.J.; Genaro, A.M.; Gorelik, G.; Barreiro Arcos, M.L.; Silberman, D.M.; Schuman, M.; Garcia, S.I.; Pirola, C.; Cremaschi, G.A. Integrative study of hypothalamus-pituitary-thyroid-immune system interaction: thyroid hormone-mediated modulation of lymphocyte activity through the protein kinase $\mathrm{C}$ signaling pathway. $J$. Endocrinol., 2006, 189(1), 45-55.

[28] Klecha, A.J.; Barreiro Arcos, M.L.; Frick, L.; Genaro, A.M.; Cremaschi, G. Immune-endocrine interactions in autoimmune thyroid diseases. Neuroimmunomodulation, 2008, 15(1), 68-75.

[29] Davis, P.J.; Zhou, M.; Davis, F.B.; Lansing, L.; Mousa, S.A.; Lin, H.Y. Mini-review: Cell surface receptor for thyroid hormone and nongenomic regulation of ion fluxes in excitable cells. Physiol. Behav. 2010, 99(2), 237-239.

[30] Bergh, J.J.; Lin, H.Y.; Lansing, L.; Mohamed, S.N.; Davis, F.B.; Mousa, S.; Davis, P.J. Integrin alphaVbeta3 contains a cell surface receptor site for thyroid hormone that is linked to activation of mitogen-activated protein kinase and induction of angiogenesis. Endocrinology, 2005, 146(7), 2864-2871.

[31] Davis, P.J.; Lin, H.Y.; Mousa, S.A.; Luidens, M.K.; Hercbergs, A.A.; Wehling, M.; Davis, F.B. Overlapping nongenomic and genomic actions of thyroid hormone and steroids. Steroids, 2011, 76(9), 829-833.

[32] Tang, H.Y.; Lin, H.Y.; Zhang, S.; Davis, F.B.; Davis, P.J. Thyroid hormone causes mitogen-activared protein kinase-dependent phosphorylation of the nuclear estrogen receptor. Endocrinology, 2004, 145(7), 3265-3272.

[33] Lin, H.Y.; Tang, H.Y.; Shih, A.; Keating, T.; Cao, G.; Davis, P.J.; Davis, F.B. Thyroid hormone is a MAPK-dependent growth factor for thyroid cancer cells and is anti-apoptotic. Steroids, 2007, 72(2), 180-187.

[34] Lin, H.Y.; Sun, M.; Tang, H.Y.; Lin, C.; Luidens, M.K.; Mousa, S.A.; Incerpi, S.; Drusano, G.L.; Davis, F.B.; Davis, P.J. LThyroxine vs. 3,5,3'-triiodo-L-thyronine and cell proliferation: activation of mitogen-activated protein kinase and phosphatidylinositol 3-kinase. Am. J. Physiol. Cell Physiol., 2009, 296(5), C980C991.

[35] Meng, R.; Tang, H.Y.; Westfall, J.; London, D.; Cao, J.H.; Mousa, S.A.; Luidens, M.; Hercbergs, A.; Davis, F.B.; Davis, P.J.; Lin,
H.Y. Crosstalk between integrin $\alpha v \beta 3$ and estrogen receptor- $\alpha$ is involved in thyroid hormone-induced proliferation in human lung carcinoma cells. PLoS One, 2011, 6(11), e27547.

[36] Davis, P.J.; Davis, F.B.; Lin, H.Y.; Mousa, S.A.; Zhou, M.; Luidens, M.K. Translational implications of nongenomic actions of thyroid hormone initiated at its integrin receptor. Am. J. Physiol. Endocrinol. Metab., 2009, 297(6), E1238-1246.

[37] Barreiro Arcos, M.L.; Gorelik, G.; Klecha, A.; Genaro, A.M.; Cremaschi, G.A. Thyroid hormones increase inducible nitric oxide synthase gene expression downstream from PKC-zeta in murine tumor T lymphocytes. Am. J. Physiol. Cell Physiol., 2006, 291(2), C327-336.

[38] Barreiro Arcos, M.L.; Sterle, H.A.; Paulazo, M.A.; Valli, E.; Klecha, A.J.; Isse, B.; Pellizas, C.G.; Farias, R.N.; Cremaschi, G.A. Cooperative nongenomic and genomic actions on thyroid hormone mediated-modulation of $\mathrm{T}$ cell proliferation involve up-regulation of thyroid hormone receptor and inducible nitric oxide synthase expression. J. Cell Physiol., 2011, 226(12), 3208-3218.

[39] Cayrol, F.; Díaz Flaqué, M.C.; Fernando, T.; Yang, S.N.; Sterle, H.A.; Bolontrade, M.; Amorós, M.; Isse, B.; Farías, R.N.; Ahn, H.; Tian, Y.F.; Tabbo, F.; Singh, A.; Inghirami, G.; Cerchietti, L.; Cremaschi, G.A. Integrin $\alpha \mathrm{V} \beta 3$ acting as membrane receptor for thyroid hormones mediates angiogenesis in malignant $\mathrm{T}$ cells. Blood, 2014, in press.

[40] Barreiro Arcos, M.L.; Sterle, H.A.; Vercelli, C.; Valli, E.; Cayrol, M.F.; Klecha, A.J.; Paulazo, M.A.; Diaz Flaqué, M.C.; Franchi, A.M.; Cremaschi, G.A. Induction of apoptosis in T lymphoma cells by long-term treatment with thyroxine involves $\mathrm{PKC} \zeta$ nitration by nitric oxide synthase. Apoptosis, 2013, 18(11), 1376-1390.

[41] Neri, A.; Marmiroli, S.; Tassone, P.; Lombardi, L.; Nobili, L.; Verdelli, D.; Civallero, M.; Cosenza, M.; Bertacchini, J.; Federico, M.; De Pol, A.; Deliliers, G.L.; Sacchi, S. The oral protein-kinase C beta inhibitor enzastaurin (LY317615) suppresses signalling through the AKT pathway, inhibits proliferation and induces apoptosis in multiple myeloma cell lines. Leuk. Lymphoma, 2008, 49(7), 1374-1383.

[42] Gibbs, P.E.; Miralem, T.; Lerner-Marmarosh, N.; Tudor, C.; Maines, M.D. Formation of ternary complex of human biliverdin reductase-protein kinase $\mathrm{C} \delta$-ERK2 protein is essential for ERK2mediated activation of Elk1 protein, nuclear factor- $\kappa \mathrm{B}$, and inducible nitric-oxidase synthase (iNOS). J. Biol. Chem., 2012, 287(2), 1066-1079.

[43] Sterle, H.A.; Valli, E.; Cayrol, F.; Paulazo, M.A.; Martinel Lamas, D.J.; Diaz Flaqué, M.C.; Klecha, A.J.; Colombo, L.; Medina, V.A.; Cremaschi, G.A.; Barreiro Arcos, M,L. Thyroid status modulates T lymphoma growth via cell cycle regulatory proteins and angiogenesis. J. Endocrinol., 2014, 222(2), 243-55.

[44] Barrera-Hernandez, G.; Park, K.S.; Dace, A.; Zhan, Q.; Cheng SY. Thyroid hormone-induced cell proliferation in GC cells is mediated by changes in G1 cyclin/cyclin-dependent kinase levels and activity. Endocrinology, 1999, 140(11), 5267-5274.

[45] Ledda-Columbano, G.M.; Molotzu, F.; Pibiri, M.; Cossu, C.; Perra, A.; Columbano, A. Thyroid hormone induces cyclin D1 nuclear translocation and DNA synthesis in adult rat cardiomyocytes. FASEB J., 2006, 20(1), 87-94.

[46] Verga Falzacappa, C., Panacchia, L.; Bucci, B.; Stigliano, A.; Cavallo, M.G.; Brunetti, E., Toscano, V.; Misiti, S. 3,5,3'triiodothyronine (T3) is a survival factor for pancreatic beta-cells undergoing apoptosis. J. Cell Physiol., 2006, 206(2), 309-321.

[47] Zhang, B.; Zhang, A.; Zhou, X.; Webb, P.; He, W.; Xia, X. Thyroid hormone analogue stimulates keratinocyte proliferation but inhibits cell differentiation in epidermis. Int. J. Immunopathol. Pharmacol., 2012, 25(4), 859-869.

[48] Mousa, S.A.; Lin, H.Y.; Tang, H.Y.; Hercbergs, A.; Luidens, M.K.; Davis, P.J. Modulation of angiogenesis by thyroid hormone and hormone analogues: implications for cancer management. Angiogenesis, 2014, 17(3), 463-469.

[49] Glinskii, A.B.; Glinsky, G.V.; Lin, H.Y.; Tang, H.Y.; Sun, M.; Davis, F.B.; Luidens, M.K.; Mousa, S.A.; Hercbergs, A.H.; Davis, P.J. Modification of survival pathway gene expression in human breast cancer cells by tetraiodothyroacetic acid (tetrac). Cell Cycle, 2009, 8(21), 3562-3570.

[50] Davis, P.J.; Davis, F.B.; Mousa, S.A.; Luidens, M.K.; Lin, H,Y. Membrane receptor for thyroid hormone: physiologic and pharmacologic implications. Annu. Rev. Pharmacol. Toxicol., 2011, 51, 99-115. 
[51] Luidens, M.K.; Mousa, S.A.; Davis, F.B.; Lin, H.Y.; Davis, P.J. Thyroid hormone and angiogenesis. Vascul. Pharmacol., 2010, $52(3-4), 142-145$

[52] Ness, R.B.; Grisso, J.A.; Cottreau, C.; Klapper, J.; Vergona, R.; Wheeler, J.E.; Morgan, M.; Schlesselman, J.J. Factors related to inflammation of the ovarian epithelium and risk of ovarian cancer. Epidemiology, 2000, 11(2), 111-117.

[53] Ko, A.H.; Wang, F.; Holly, E.A. Pancreatic cancer and medical history in a population-based case-control study in the San Francisco Bay Area, California. Cancer Causes Control, 2007, 18(8), 809-819.

[54] Moeller, L.C.; Führer, D. Thyroid hormone, thyroid hormone receptors, and cancer: a clinical perspective. Endocr Relat Cancer, 2013, 20(2), R19-29.

[55] Toms, S.A.; Hercbergs, A.; Liu, J.; Kondo, S.; Haqqi, T.; Casey, G.; Iwasaki, K.; Barnett, G.H.; Barna, B.P. Antagonist effect of insulin-like growth factor I on protein kinase inhibitor-mediated apoptosis in human glioblastoma cells in association with bcl-2 and bcl-xL. J. Neurosurg., 1998, 88(5), 884-889.

[56] Cristofanilli, M.; Yamamura, Y.; Kau, S.W.; Bevers, T.; Strom, S.; Patangan, M.; Hsu, L.; Krishnamurthy, S.; Theriault, R.L.; Hortobagyi, G.N. Thyroid hormone and breast carcinoma. Primary hypothyroidism is associated with a reduced incidence of primary breast carcinoma. Cancer, 2005, 103(6), 1122-1128.

[57] Hercbergs, A. Spontaneous remission of cancer--a thyroid hormone dependent phenomenon? Anticancer Res., 1999, 19(6A), 48394844.

[58] Reddy, A.; Dash, C.; Leerapun, A.; Mettler, T.A.; Stadheim, L.M.; Lazaridis, K.N.; Roberts, R.O.; Roberts, L.R. Hypothyroidism: a possible risk factor for liver cancer in patients with no known underlying cause of liver disease. Clin. Gastroenterol Hepatol., 2007, 5(1), 118-123.

[59] Kuijpens, J.L.; Nyklíctek, I.; Louwman, M.W.; Weetman, T.A.; Pop, V.J.; Coebergh, J.W. Hypothyroidism might be related to breast cancer in post-menopausal women. Thyroid, 2005, 15(11), 1253-1259.

[60] Barreiro Arcos, M.L.; Klecha, A.J.; Genaro, A.M.; Cremaschi, G.A. Immune System Modulation by Thyroid Axis Includes Direct Genomic and Nongenomic Actions of Thyroid Hormones on Immune Cells. Immun., Endoc. \& Metab. Agents in Med. Chem., 2010, 10, 1-10.

[61] Sánchez-Beato, M.; Sánchez-Aguilera, A.; Piris, M.A. Cell cycle deregulation in B-cell lymphomas. Blood, 2003, 101, 1220-1235.

[62] Martínez-Iglesias, O.; García-Silva, S.; Regadera, J.; Aranda, A. Hypothyroidism enhances tumor invasiveness and metastasis development. PLoS One, 2009, 4(7), e6428.

[63] Zukerberg, L.R.; Yang, W.I.; Arnold, A.; Harris, N.L. Cyclin D1 expression in non-Hodgkin's lymphomas. Detection by immunohistochemistry. Am. J. Clin. Pathol., 1995, 103, 756-760.

[64] Kanavaros, P.; Bai, M.; Stefanaki, K.; Poussias, G.; Rontogianni, D.; Zioga, E.; Gorgoulis, V.; Agnantis, N.J. Immunohistochemical expression of the p53, mdm2, p21/Waf-1, Rb, p16, Ki67, cyclin $\mathrm{D} 1$, cyclin A and cyclin B1 proteins and apoptotic index in T-cell lymphomas. Histol. Histopathol., 2001, 16, 377-386.

[65] Mao, X.; Orchard, G.; Vonderheid, E.C.; Novell, P.C.; Bagot, M., Bensussan, A.; Russell-Jones, R.; Young, B.D.; Whittaker, S.J.
Heterogeneous abnormalities of CCND1 and RB1 in primary cutaneous T-Cell lymphomas suggesting impaired cell cycle control in disease pathogenesis. J. Invest. Dermatol., 2006, 126, 1388-1395.

[66] Doglioni, C.; Chiarelli, C.; Macro, E.; Dei Tos, A.P.; Meggiolaro, E.; Dalla Palma, P.; Barbareschi, M. Cyclin D3 expression in normal, reactive and neoplastic tissues. J. Pathol., 1998, 185(2), 159-166.

[67] Møller, M.B.; Nielsen, O.; Pedersen, N.T. Cyclin D3 expression in non-Hodgkin lymphoma. Correlation with other cell cycle regulators and clinical features. Am. J. Clin. Pathol., 2001, 115(3), 404412.

[68] Opavsky, R.; Wang, S.H.; Trikha, P.; Raval, A.; Huang, Y.; Wu, Y.Z.; Rodríguez, B.; Keller, B.; Liyanarachchi, S.; Wei, G.; Davuluri, R.V.; Weinstein, M.; Felsher, D.; Ostrowski, M.; Leone, G.; Plass, C. CpG island methylation in a mouse model of lymphoma is driven by the genetic configuration of tumor cells. PLoS Genet., 2007, 3, 1757-1769.

[69] Pérez de Castro, I.P.; Malumbres, M.; Santos, J.; Pellicer, A.; Fernández-Piqueras, J. Cooperative alterations of $\mathrm{Rb}$ pathway regulators in mouse primary T cell lymphomas. Carcinogenesis, 1999, $20,1675-1682$

[70] Møller, M.B.; Nielsen, O.; Pedersen, N.T. Frequent alteration of MDM2 and $\mathrm{p} 53$ in the molecular progression of recurring nonHodgkin's lymphoma. Histopathology, 2002, 41(4), 322-330.

[71] Verschuren, E.W.; Hodgson, J.G.; Gray, J.W.; Kogan, S.; Jones, N.; Evan, G.I. The role of p53 in suppression of KSHV cyclininduced lymphomagenesis. Cancer Res., 2004, 64(2), 581-589.

[72] Karsunky, H.; Guisen, C.; Schmidt, T.; Haas, K.; Zevnik, B.; Gau, E.; Möröy T. Oncogenic potential of cyclin E in T-cell lymphomagenesis in transgenic mice: evidence for cooperation between cyclin E and Ras but not Myc. Oncogene, 1999, 18(54), 7816-24.

[73] Martins, C.P.; Berns, A. Loss of p27(Kip1) but not p21(Cip1) decreases survival and synergizes with MYC in murine lymphomagenesis. EMBO J., 2002, 21, 3739-3748.

[74] Kang-Decker, N.; Tong, C.; Boussouar, F.; Baker, D.J.; Xu, W ; Leontovich, A.A.; Taylor, W.R.; Brindle, P.K.; van Deursen, J.M. Loss of CBP causes $\mathrm{T}$ cell lymphomagenesis in synergy with p27Kip1 insufficiency. Cancer Cell., 2004, 5(2),177-189.

[75] Alisi, A.; Demori, I.; Spagnuolo, S.; Pierantozzi, E.; Fugassa, E.; Leoni, S. Thyroid status affects rat liver regeneration after partial hepatectomy by regulating cell cycle and apoptosis. Cell. Physiol. Biochem., 2005, 15(1-4), 69-76.

[76] Zhang, L.; Cooper-Kuhn, C.M.; Nannmark, U.; Blomgren, K.; Kuhn, H.G. Stimulatory effects of thyroid hormone on brain angiogenesis in vivo and in vitro. J. Cereb. Blood Flow Metab., 2010, 30(2), 323-335.

[77] Otto, T.; Fandrey, J. Thyroid hormone induces hypoxia-inducible factor 1alpha gene expression through thyroid hormone receptor beta/retinoid $\mathrm{x}$ receptor alpha-dependent activation of hepatic leukemia factor. Endocrinology, 2008, 149(5), 2241-2250.

[78] Davis, F.B.; Mousa, S.A.; O'Connor, L.; Mohamed, S.; Lin, H.Y Cao, H.J.; Davis, P.J. Proangiogenic action of thyroid hormone is fibroblast growth factor-dependent and is initiated at the cell surface. Circ Res., 2004, 94(11), 1500-1506.

[79] Pinto, M.; Soares, P.; Ribatti, D. Thyroid hormone as a regulator of tumor induced angiogenesis. Cancer Lett., 2011, 301(2), 119-126. 